\title{
Adrenal Function during Topical Oral Corticosteroid Treatment
}

\author{
THOMAS LEHNER,* M.D., F.D.S., M.C.PATH. ; CYNTHIA LYNE, † B.SC.
}

\begin{abstract}
ummary : Plasma cortisol (hydrocortisone) levels were measured in 42 subjects before and during administration of topical oral corticosteroids. Topical administration of $0.3-0.4 \mathrm{mg}$. of betamethasone disodium phosphate daily caused partial suppression of adrenal function in 8 out of 10 subjects tested. The adrenal function remained normal in 14 patients treated with $10 \mathrm{mg}$. of hydrocortisone hemisuccinate daily for periods of up to three years. Betamethasone 17-valerate also failed to cause adrenal suppression in doses of $0.4 \mathrm{mg}$. per day in 17 patients. The adrenal glands failed to respond normally to stimulation with Synacthen (tetracosactrin) in selected subjects with depressed plasma cortisol levels. Therapeutic doses of topical oral hydrocortisone hemisuccinate and betamethasone 17-valerate may be used in adults with oral lesions without fear of affecting adrenal function. Betamethasone disodium phosphate, however, should be avoided, as it may cause adrenal suppression.
\end{abstract}

\section{Introduction}

Small doses of topical corticosteroid drugs have been widely used in the treatment of recurrent aphthous ulcers since the efficacy of hydrocortisone hemisuccinate was shown by Truelove and Morris-Owen (1958) and by Cooke and Armitage (1960). Betamethasone disodium phosphate was later introduced as a more potent preparation, and the use of topical oral steroids has been extended to other oral diseases. Recently, betamethasone 17-valerate was found to be effective in oral lichen planus and possibly in benign mucous membrane pemphigus by Cawson (1968).

Although the effect of topical oral steroids on the pituitaryadrenal function has not been investigated comprehensively in the past, it has been widely assumed that adrenal suppression is unlikely to occur because the dose of exogenous steroids has been kept low. Percutaneous absorption of a variety of steroids, however, can cause pituitary-adrenal suppression (Scoggins, 1962 ; Scoggins and Kliman, 1965). Small doses of triamcinolone acetonide applied to skin induced suppression of plasma cortisol levels (Keczkes et al., 1967), though beclomethasone dipropionate did not produce the same effect (Raffle and Frain-Bell, 1967). The type of steroid is therefore one factor that determines whether adrenal suppression will occur. The dose is another factor, for Friedman et al. (1967) have shown that 2-4 mg. of oral betamethasone 17 -valerate daily failed to induce adrenal suppression, but $8 \mathrm{mg}$. produced this effect. Recently, $0.4 \mathrm{mg}$. of topical oral betamethasone disodium phosphate per day caused adrenal suppression in one patient (MacPhee et al., 1968). Since adrenal function is greatly influenced by individual sensitivity (Hicklin and Wills, 1968), the results in one patient should be viewed with caution.

An assessment of the safety of topical oral steroid therapy is evidently desirable. The purpose of this investigation was to find out if under clinical conditions three topical oral steroids induce adrenal suppression. Plasma cortisol levels were estimated in 42 subjects before and during treatment for a period of up to three years. Adrenocortical function was

* Reader in Pathology in Relation to Oral Disease.

+ Research Associate in the Interdepartmental Laboratory.

Guy's Hospital Medical School, London S.E.1. tested in selected subjects by means of the synthetic corticotrophin Synacthen (tetracosactrin) (Wood et al., 1965).

\section{Subjects and Methods}

Patients with lesions for which topical steroids are commonly used in clinical practice were selected from the oral medicine clinic; 17 had recurrent aphthous ulcers, 14 lichen planus (seven of the erosive variety), three erythema migrans linguae, and three benign mucous membrane pemphigus. Also included were five normal subjects with intact oral mucosa. The three test steroids were administered in tablets that were allowed to dissolve in the mouth. Fourteen subjects were given hydrocortisone hemisuccinate (Corlan, $2.5 \mathrm{mg}$. per tablet), 11 had betamethasone disodium phosphate (Beta-Corlan, $0.1 \mathrm{mg}$. per tablet), and 17 had betamethasone 17 -valerate (Betnovate, $0.1 \mathrm{mg}$. per tablet). These drugs were administered four times daily (with two exceptions) throughout the test period, which lasted from two days to eight months, in order to assess the maximum dose of topical steroids over a short-term and a long-term period. In three patients (Cases 9, 10, and 11) hydrocortisone was used only intermittently-that is, when ulceration reappeared, over a period of one to three years. The effect of successive administration of different steroids has also been tested in 15 patients. These patients were treated with other steroids immediately preceding this study (Tables I-III). Many patients, however, must have had some topical steroids in the past, but this could not be recorded with any accuracy.

Plasma cortisol levels were estimated before and at about twomonthly intervals during administration of the steroids. Tenmillilitre samples of lithium heparinized blood were collected at a set time of the day (mostly 11 a.m. to 12.30 p.m.) and the separated plasma was stored at $-20^{\circ} \mathrm{C}$. Betamethasone disodium phosphate and betamethasone 17-valerate do not interfere significantly with estimation of plasma cortisol, but, as the technique does not differentiate between hydrocortisone secreted by the adrenal gland and that administered externally, patients were given instructions not to take hydrocortisone 12 hours before the test.

The tetracosactrin test was performed in three subjects on betamethasone disodium phosphate whose cortisol levels fell to $3.9,4 \cdot 3$, and $7 \cdot 2 \mu \mathrm{g} . / 100 \mathrm{ml}$., by collecting $10-\mathrm{ml}$. blood samples just before and 30 and 60 minutes after an intramuscular injection of $250 \mu \mathrm{g}$. of tetracosactrin. The results were compared with those of 30 randomly selected inpatients who were free of any endocrine abnormality and did not receive steroid treatment.

The plasma cortisol was measured as free 11-hydroxycorticosteroid by the fluorimetric method of Mattingly (1962). This was modified for better sensitivity by centrifuging the methylene dichloride extracts, to remove interfering liquids in the aqueous phase (Lessof et al., 1969). With this method the range of plasma cortisol in 50 normal subjects was $8-28$ (mean $17 \cdot 4 \pm 6$ ) $\mu \mathrm{g} . / 100 \mathrm{ml}$. at $9-10$ a.m., $10-17$ (mean $14 \cdot 7 \pm 2 \cdot 8$ ) $\mu \mathrm{g} / 100 \mathrm{ml}$. at 2 p.m., and $6-15$ (mean $10 \cdot 4 \pm 4 \cdot 1$ ) $\mu \mathrm{g} . / 100 \mathrm{ml}$. at $8 \mathrm{p.m}$. (McHardy-Young et al., 1967). The reproducibility of this assay is satisfactory, since $94 \%$ of duplicate tests on 142 samples varied by less than $\pm 6 \%$. As most of the present blood samples were taken at 11 a.m. to noon, the range of plasma cortisol levels at that time was determined in 20 normal subjects. 


\section{Results}

Some clinical data and the cortisol levels of individual patients are shown in Tables I-III ; the lowest levels during steroid treatment are recorded in Fig. 1.

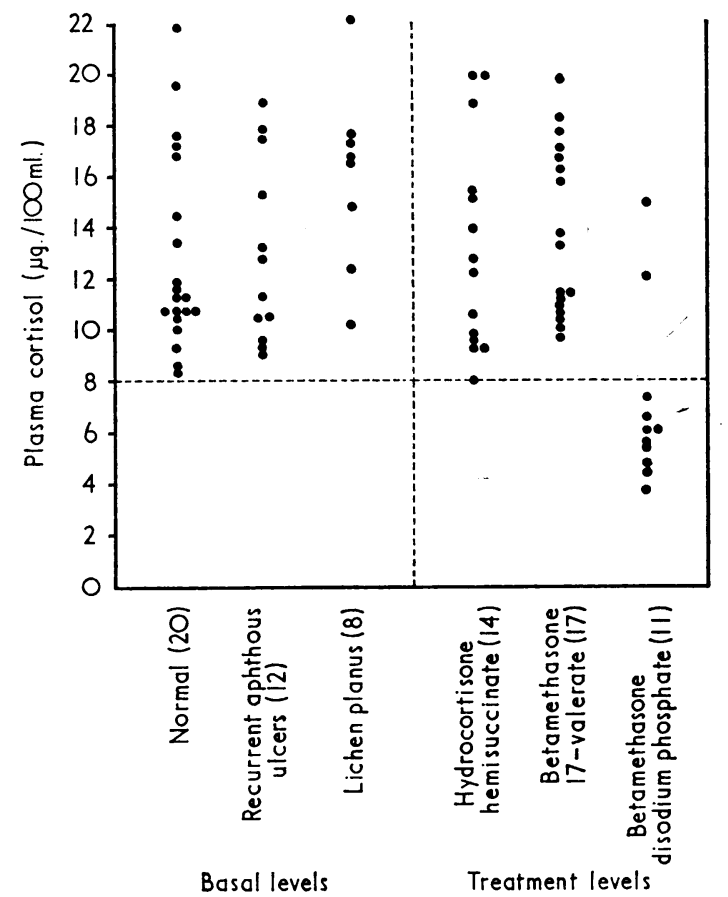

FIG. 1.-Lowest plasma cortisol levels during topical administration of hydrocortisone hemisuccinate, betametha-

Controls.-The range of plasma cortisol in 20 normal subjects was $8 \cdot 5-21.9$ (mean $13 \cdot 5 \pm 4.3$ ) $\mu \mathrm{g} . / 100 \mathrm{ml}$. at 11 a.m. to noon.

Hydrocortisone Hemisuccinate.-None of the plasma cortisol levels fell below $8 \mu \mathrm{g} . / 100 \mathrm{ml}$. (Table I ; Fig. 1). This was found not only in patients on short-term treatment but also in those taking the steroid for up to three years. Unfortunately, baseline cortisol levels in three patients on long-term steroids are not available. Previous administration of triamcinolone acetonide in orabase had no apparent effect on the cortisol levels of patients whose treatment has been changed to hydrocortisone hemisuccinate.
Betamethasone 17-valerate.-This also failed to suppress the plasma cortisol level (Table II ; Fig. 1). The longest period of observation, however, extended only over eight months. The

TABLE I.-Plasma Cortisol Levels ( $\mu \mathrm{g.} / 100 \mathrm{ml}$.) Before and During Topical Oral Administration of $10 \mathrm{mg}$. of Hydrocortisone Hemisuccinate Daily

\begin{tabular}{|c|c|c|c|c|c|c|c|}
\hline \multirow{2}{*}{$\begin{array}{l}\text { Case } \\
\text { No. }\end{array}$} & \multirow{2}{*}{$\begin{array}{l}\text { Sex } \\
\text { and } \\
\text { Age }\end{array}$} & \multirow{2}{*}{ Diagnosis } & \multirow{2}{*}{$\begin{array}{l}\text { Before } \\
\text { Treat- } \\
\text { ment }\end{array}$} & \multicolumn{4}{|c|}{ Months after Start of Treatment } \\
\hline & & & & 1 & $2-3$ & $4-6$ & $12-36$ \\
\hline 1 & M 37 & Normal $\quad \ldots$ & $10 \cdot 7$ & $* 9 \cdot 5,14 \cdot 4$ & - & - & - \\
\hline $\begin{array}{l}2 \\
3\end{array}$ & $\begin{array}{ll}\mathrm{F} & 23 \\
\mathrm{~F} & 22\end{array}$ & $\begin{array}{l}\text { Normal } \\
\text { Erythema }\end{array}$ & $10 \cdot 8$ & $* 8 \cdot 0,8 \cdot 5$ & - & - & - \\
\hline & & migrans & $17 \cdot 0$ & $19 \cdot 9$ & - & - & - \\
\hline 4 & M 39 & $\begin{array}{l}\text { Erythema } \\
\text { migrans }\end{array}$ & $15 \cdot 0$ & $15 \cdot 6$ & - & - & - \\
\hline 5 & F 36 & $\begin{array}{l}\text { Benign mucous } \\
\text { membrane } \\
\text { pemphigus }\end{array}$ & $10 \cdot 9$ & $12 \cdot 9$ & $16 \cdot 0$ & - & - \\
\hline 6 & F 18 & $\begin{array}{l}\text { Major aphthous } \\
\text { ulcers }\end{array}$ & $10 \cdot 5$ & $13 \cdot 2$ & $9 \cdot 7$ & - & - \\
\hline $\begin{array}{l}7 \\
8\end{array}$ & $\begin{array}{ll}\text { F } & 67 \\
\text { M } & 19\end{array}$ & $\begin{array}{l}\text { Lichen planus } \\
\text { Minor aphthous } \\
\text { ulcers }\end{array}$ & $\begin{array}{l}10 \cdot 1 \\
11 \cdot 3\end{array}$ & $\begin{array}{l}10 \cdot 6 \\
14 \cdot 0\end{array}$ & $14 \cdot 0$ & $19 \cdot 4$ & - \\
\hline 9 & F 43 & Lich"en planus & 二 & 二 & - & 二 & $\begin{array}{r}9 \cdot 4 \\
15 \cdot 2\end{array}$ \\
\hline 11 . & F 68 & $\begin{array}{l}\text { Lichen planus } \\
\text { (erosive) }\end{array}$ & 一 & - & - & - & $9 \cdot 8$ \\
\hline $12 t$ & F 37 & $\begin{array}{l}\text { Major aphthous } \\
\text { ulcers }\end{array}$ & $21 \cdot 0$ & 一 & $18 \cdot 8$ & - & - \\
\hline $\begin{array}{l}13 t \\
14 t\end{array}$ & $\begin{array}{ll}\text { F } & 23 \\
\text { F } & 21\end{array}$ & " " & $\begin{array}{l}10 \cdot 8 \\
18 \cdot 4\end{array}$ & 二 & $\begin{array}{l}12 \cdot 5 \\
21 \cdot 8\end{array}$ & $\overline{19 \cdot 9}$ & 二 \\
\hline
\end{tabular}

Cortisol level one to three days after start of treatment

Crevious treatment with triamcinolone in orabase q.d.s. for 2 months in Cases 12 and 13 and for six months in Case 14 .

daily dose was raised to $1.2 \mathrm{mg}$. for three days in a normal subject (Case 31 ; Table II), and the cortisol level remained unchanged.

Betamethasone Disodium Phosphate.-This depressed the cortisol level below $8 \mu \mathrm{g} . / 100 \mathrm{ml}$. in all six subjects (Table III). Five of these were taking $0.4 \mathrm{mg}$. of betamethasone disodium phosphate daily, and their cortisol levels fell to $5.5 \mu \mathrm{g}$. in two days (Case 32), 4.8 $\mu \mathrm{g}$. in two days (Case 33), 6.1 $\mu \mathrm{g}$. in four days (Case 34), 6.1 $\mu \mathrm{g}$. in three months (Case 36), and 6.5 $\mu \mathrm{g}$. in eight months (Case 37). The dosage in one patient was maintained at $0.3 \mathrm{mg}$. daily (Case 35 ) and the cortisol level fell to $7 \cdot 2 \mu \mathrm{g}$. within two months and to $3.9 \mu \mathrm{g} . / 100 \mathrm{ml}$. after three months of treatment. Thus topical administration of 0.3 or $0.4 \mathrm{mg}$. daily can induce adrenal suppression. Of the five patients who were treated with other steroids immediately before betamethasone disodium phosphate was used, three showed adrenal suppression (Cases 39, 41, and 42; Table III). Only one patient in this series (Case 41) had a "resting" plasma level under $8 \mu \mathrm{g} . / 100 \mathrm{ml}$.; he had been treated in the past with a variety of steroids, the nature of which could not be ascertained. The baseline level in Case 42 was not available, but this woman had a low plasma cortisol level after a daily

TABLE II.-Plasma Cortisol Levels ( $\mu \mathrm{g} . / 100 \mathrm{ml}$.) Before and During Topical Oral Administration of 0.4 mg. of Betamethasone 17-Valerate Daily

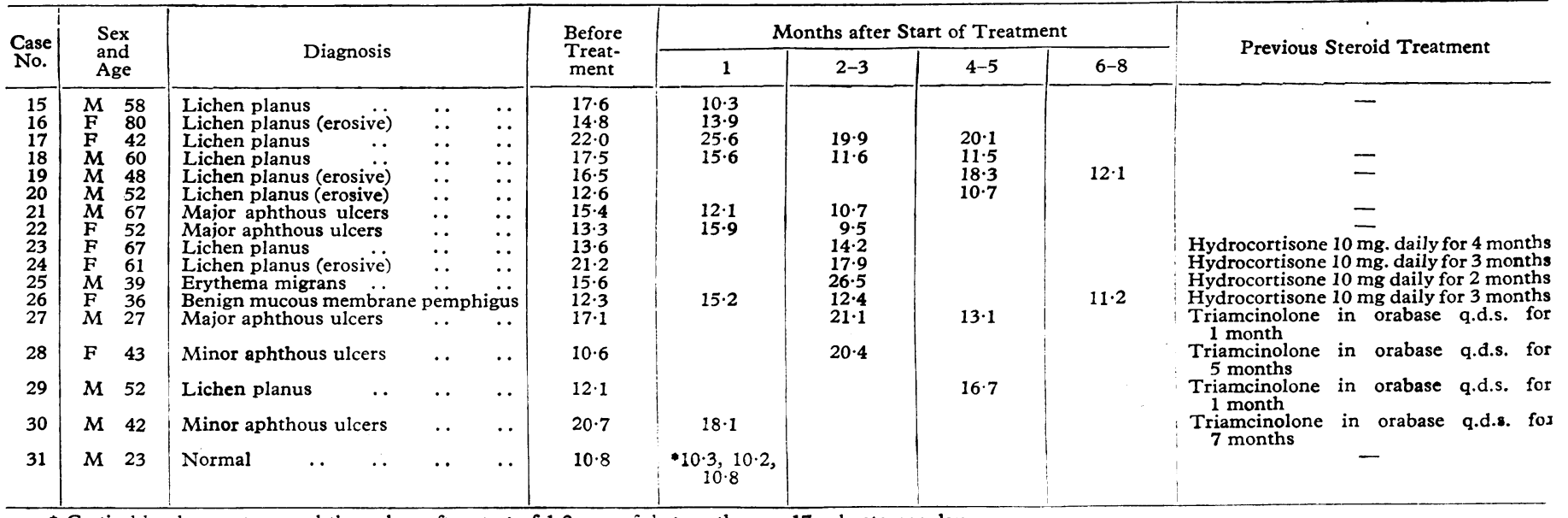


dose of $0.2 \mathrm{mg}$. of betamethasone disodium phosphate. She was, however, using topical triamcinolone in orabase in addition to betamethasone disodium phosphate, so that the low cortisol level may be due to a combined effect of two steroids. Normal levels were re-established, if estimated one day (Case 32 ; Fig. 2) 10 days (Case 33 ; Fig. 2), or two months (Cases 35,36 , and 39) after the steroid was stopped.
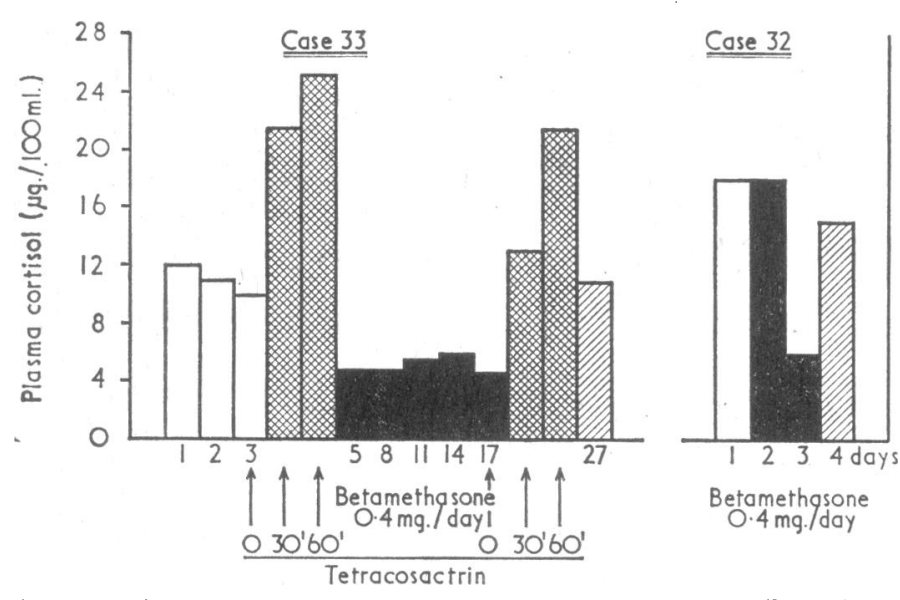

FIG. 2.- Plasma cortisol levels before $\square$, during $\square$ and after $I / /$ topical oral application of $0.4 \mathrm{mg}$. betamethasone disodium phosphate daily; tetracosactrin test before and after the steroid.

Tetracosactrin Test.-All three subjects failed to reach the minimum level of $21.5 \mu \mathrm{g}$. recorded within 30 minutes in the controls, and only one patient rose to the minimum level 60 minutes after administration of tetracosactrin (Table IV). The response to tetracosactrin in one subject before the application of steroid was normal, but after daily administration of $0.4 \mathrm{mg}$. of betamethasone disodium phosphate for 12 days the response was deficient within both 30 and 60 minutes of injection of tetracosactrin (Fig. 2).

\section{Discussion}

A striking difference was found between the effect of topical betamethasone disodium phosphate and that of hydrocortisone hemisuccinate and betamethasone 17-valerate (Fig. 1). Plasma cortisol levels in persons on the latter two steroids were over or. at $8 \mu \mathrm{g} . / 100 \mathrm{ml}$. All but two of the 11 subjects receiving betamethasone disodium phosphate showed cortisol levels less than $8 \mu \mathrm{g} . / 100 \mathrm{ml}$. The two exceptions (Cases 38 and 40 ; Table III) had had hydrocortisone or betamethasone 17-valerate for two months before administration of betamethasone disodium phosphate, but it is difficult to see how this could account for the cortisol levels remaining normal.
Normal levels of plasma cortisol vary with different laboratories and the time of the day when blood is collected. In this study, however, comparison of cortisol levels before and during TABLE IV.-Plasma Cortisol Levels ( $\mu \mathrm{g} . / 100 \mathrm{ml}$.) After Administration of $250 \mu \mathrm{g}$. of Tetracosactrin

\begin{tabular}{|c|c|c|c|c|}
\hline \multirow{2}{*}{ Subjects } & \multicolumn{3}{|c|}{ Time } & \multirow{2}{*}{$\begin{array}{l}\text { Betamethasone } \\
\text { Disodium } \\
\text { Phosphate }\end{array}$} \\
\hline & 0 & $30 \mathrm{~min}$. & $60 \mathrm{~min}$. & \\
\hline $\left.\begin{array}{cc}\begin{array}{c}30 \\
\text { controls }\end{array} \\
\text { Case 33 }\end{array}\right\} \begin{array}{c}\text { Mean } \\
\text { Range } \\
\text { Case 35 }\end{array}$ & $\begin{array}{c}12 \cdot 8 \\
7 \cdot 2-18 \cdot 6 \\
4 \cdot 3 \\
3 \cdot 9 \\
7 \cdot 2\end{array}$ & $\begin{array}{c}29 \cdot 6 \\
21 \cdot 5-39 \cdot 2 \\
13 \cdot 1 \\
14 \cdot 2 \\
18 \cdot 5\end{array}$ & $\begin{array}{c}34 \cdot 5 \\
25 \cdot 3-41 \cdot 4 \\
21 \cdot 5 \\
19 \cdot 2 \\
25 \cdot 9\end{array}$ & $\begin{array}{l}0.4 \mathrm{mg} \text {. daily for } 12 \text { days } \\
0.3 \mathrm{mg} \text {. daily for } 3 \text { months } \\
0.3 \mathrm{mg} \text {. daily for } 2 \text { days }\end{array}$ \\
\hline
\end{tabular}

administration of betamethasone disodium phosphate (Table III), and the latter with levels in normal subjects and with those receiving other steroids (Fig. 1), leaves little doubt that betamethasone induces partial suppression of adrenal function. The adrenal response to tetracosactrin was abnormal in three subjects during or just after administration of $0.3-0.4 \mathrm{mg}$. of betamethasone disodium phosphate per day. Suppression of adrenocorticotrophic hormone secretion has not been tested with metyrapone or vasopressin, but only high doses of potent steroids (over $40 \mathrm{mg}$. of prednisone) for long periods (over three years) may occasionally cause this effect (El-Shaboury, 1966).

Hydrocortisone hemisuccinate failed to induce suppression of adrenal function in daily doses of $10 \mathrm{mg}$., if used for periods of days, months, or years. Similarly, $0.4 \mathrm{mg}$. of betamethasone 17-valerate daily did not affect the plasma cortisol levels in 16 subjects over a period of up to eight months. Increasing the dose to $1.2 \mathrm{mg}$. daily had no effect on the plasma cortisol levels. Indeed, this was the expected finding, since Friedman et al. (1967) did not record adrenal suppression with doses of up to $4 \mathrm{mg}$. of betamethasone 17 -valerate taken by mouth It should, however, be noted that $0.4 \mathrm{mg}$./day of a nasal spray of betamethasone 17-valerate induced adrenal suppression in 1 out of 12 patients with allergic or vasomotor rhinitis (Czarny and Brostoff, 1968).

Betamethasone disodium phosphate was capable of suppressing adrenal function within two days of topical application, so that the duration of administration does not seem to be an essential factor. Absorption of the steroid was not dependent on the presence of ulcerated mucous membrane, as the investigation recorded in Fig. 2 was performed on two normal subjects with intact oral mucosa. The dosage used $(0.4 \mathrm{mg}$./day) was very low, but even $0.3 \mathrm{mg}$. daily depressed adrenal function (Case 35). Although adrenal suppression is greatly influenced by individual sensitivity (Hicklin and Wills, 1968) the overall response to low doses of betamethasone disodium phosphate was constant enough to exclude such a factor. The potency of this steroid may be of importance, since it is 33 times as potent as hydrocortisone in terms of its anti-inflammatory action (Laurence, 1966).

TABle III.-Plasma Cortisol Levels Before, During, and After Topical Oral Administration of Betamethasone Disodium Phosphate

\begin{tabular}{|c|c|c|c|c|c|c|c|c|c|c|c|c|c|}
\hline \multirow{2}{*}{$\begin{array}{l}\text { Case } \\
\text { No. }\end{array}$} & \multirow{2}{*}{\multicolumn{2}{|c|}{$\begin{array}{l}\text { Sex and } \\
\text { Age }\end{array}$}} & \multirow{2}{*}{\multicolumn{5}{|c|}{ Diagnosis }} & \multirow{2}{*}{$\begin{array}{c}\text { Before } \\
\text { Treatment } \\
(\mu \mathrm{g} .1 \\
100 \mathrm{ml} .) \\
\end{array}$} & \multicolumn{3}{|c|}{ During Treatment } & \multirow{2}{*}{$\begin{array}{c}\text { After } \\
\text { Treatment } \\
(\mu \mathrm{g} .1 \\
100 \mathrm{ml} .)\end{array}$} & \multirow{2}{*}{$\begin{array}{c}\text { Previous Steroid } \\
\text { Treatment }\end{array}$} \\
\hline & & & & & & & & & $\begin{array}{c}\mu \mathrm{g} . / \\
100 \mathrm{ml}\end{array}$ & $\begin{array}{l}\text { Duration } \\
\text { (Months) }\end{array}$ & $\begin{array}{l}\text { Total Dose } \\
\text { (mg.) }\end{array}$ & & \\
\hline 32 & & 22 & Normal & . & $\cdots$ & ・. & $\cdots$ & $17 \cdot 7$ & \multirow{6}{*}{$\begin{array}{r}17 \cdot 7 \\
5.5 \\
4.8 \\
4.3 \\
6 \cdot 1 \\
7 \cdot 2 \\
3.9 \\
6.2 \\
6 \cdot 1 \\
6 \cdot 3 \\
8.5 \\
6.1 \\
6.5\end{array}$} & \multirow{6}{*}{$\begin{array}{c}1^{*} \\
2^{*} \\
2^{*} \\
12^{*} \\
4^{*} \\
2 \\
3 \\
8 \\
3 \\
4 \\
6 \\
7 \\
8\end{array}$} & \multirow{6}{*}{$\begin{array}{c}0 \cdot 4 \\
0 \cdot 8 \\
0 \cdot 8 \\
5 \cdot 6 \\
1 \cdot 6 \\
18 \\
27 \\
40 \\
27 \\
36 \\
48 \\
50 \\
96\end{array}$} & $14 \cdot 7$ & \multirow{8}{*}{$\begin{array}{l}\text {. } \\
\text { Hydrocortisone } 10 \mathrm{mg} \text {. daily for } 2 \text { months } \\
\text { Hydrocortisone } 10 \mathrm{mg} \text {. daily for } 4 \text { months } \\
\text { Betamethasone } 17 \text {-valerate } 0.4 \text { mg. daily } \\
\text { for } 2 \text { months } \\
\text { Topical "steroids" for } 2 \text { years } \\
\text { Triamcinolone in orabase b.d. for.3.years }\end{array}$} \\
\hline 33 & $M$ & 26 & Normal & .. & .. & .. & .. & $10 \cdot 9$ & & & & $10 \cdot 6$ & \\
\hline 34 & $\mathbf{F}$ & 22 & Minor ap & ious & ers & .. & .. & $9 \cdot 6$ & & & & & \\
\hline 35 & $\mathrm{~F}$ & 27 & Major ap & ous u & & .. & .. & $17 \cdot 7$ & & & & $11 \cdot 9$ & \\
\hline 36 & & & Major ap & ous v & ers & .. & $\cdots$ & & & & & 11.5 & \\
\hline 37 & $\mathbf{F}$ & 71 & Lichen $p$ & us (er & ive) & .. & $\cdots$ & $10 \cdot 6$ & & & & & \\
\hline $\begin{array}{l}38 \\
39 \\
40\end{array}$ & $\begin{array}{l}\mathrm{F} \\
\mathrm{F}\end{array}$ & $\begin{array}{l}36 \\
18 \\
52\end{array}$ & \multicolumn{4}{|c|}{$\begin{array}{l}\text { Mucous membrane pemphigus } \\
\text { Major aphthous ulcers } \\
\text { Major aphthous ulcers }\end{array}$} & $\because$ & $\begin{array}{r}16.0 \\
9.7 \\
9.5\end{array}$ & $\begin{array}{r}12 \cdot 3 \\
4 \cdot 6 \\
14 \cdot 9\end{array}$ & $\begin{array}{l}2 \\
4 \\
1\end{array}$ & $\begin{array}{l}18 \\
36 \\
12\end{array}$ & \multirow[t]{2}{*}{$\mathrm{i} 1 \cdot 7$} & \\
\hline $\begin{array}{l}41 \\
42\end{array}$ & $\underset{\mathbf{F}}{\mathbf{M}}$ & $\begin{array}{l}30 \\
63\end{array}$ & $\begin{array}{l}\text { Major ap. } \\
\text { Lichen p }\end{array}$ & $\begin{array}{l}\text { lous y } \\
\text { us (ex }\end{array}$ & $\begin{array}{l}\text { ers } \\
\text { ive) }\end{array}$ & $\because$ & $\because$ & $5 \cdot 9$ & $\begin{array}{l}7 \cdot 1 \\
5 \cdot 6\end{array}$ & $\begin{array}{l}1 \\
15\end{array}$ & $\begin{array}{r}9 \\
24\end{array}$ & & \\
\hline
\end{tabular}


The results of this investigation suggest that the use of betamethasone disodium phosphate in the treatment of oral ulcers is commonly associated with adrenal suppression; administration of this steroid in oral lesions cannot therefore be justified any more. Indeed, topical oral betamethasone disodium phosphate is no longer available in this country. However, therapeutic doses of topical hydrocortisone hemisuccinate and betamethasone 17-valerate do not impair adrenal function in adults. Their efficacy in the treatment of recurrent aphthous ulceration (Cooke and Armitage, 1960) and oral lichen planus (Cawson, 1968) has been established. It should be borne in mind that, while minor aphthous ulcers are often trivial and do not always require treatment, patients with major aphthous ulcers (Lehner, 1968) require constant attention and topical steroids cannot be withheld. Evidence in favour of an autoimmune pathogenesis of recurrent aphthous ulcers (Lehner, $1964,1969)$ has rationalized the use of steroids in this condition.

We wish to thank Glaxo Laboratories for their assistance and the medical illustration department for the illustrations. We are grateful to our colleagues who volunteered for some of the tests.

\section{REFERENCES}

Cawson, R. A. (1968). British-Medical fournal, 1, 86.

Cooke, B. E. D., and Armitage, P. (1960). British Medical fournal, 1,
Czarny, D., and Brostoff, J. (1968). Lancet, 2, 188.

El-Shaboury, A. H. M. (1966) MD. Thesis, University of Wales. Quoted by Picton Thomas, 1968, Guide to Steroid Therapy. Quoted by Picton

Friedman, M., Fletcher, J., Hinton, J. M., Lennard-Jones, J. E., Misiewicz, J. J., and Parrish, J. A. (1967). British Medical fournal, Misiewic 335 .

Hicklin, J. A., and Wills, M. R. (1968). Annals of the Rheumatic Diseases, 27, 33

Keczkes, K., Frain-Bell, W., Honeyman, A. L., and Sprunt, G. (1967) British fournal of Dermatology, 79, 475.

Laurence, D. R. (1966). Clinical Pharmacology, 3rd ed. London, Churchill.

Lehner, T. (1964). Lancet, 2, 1154.

Lehner, T. (1968). Proceedings of the Royal Society of Medicine, 61, 19.

Lehner, T. (1969). Archives of Oral Biology, 14, 843.

Lessof, M. H., Lyne, Cynthia, Maisey, M. N., and Sturge, R. A. (1969). Lancet, 1, 642.

McHardy-Young, S., Harris, P. W. R., Lessof, M. H., and Lyne, Cynthia (1967). British Medical fournal, 2, 740.

MacPhee, I. T., Sircus, W., Farmer, E. D., Harkness, R. A., and Cowley, G." C. (1968). British Medical fourmal, 2, 147.

Mattingly, D. (1962). Fournal of Clinical Pathology, 15, 374.

Raffle, E. J., and Frain-Bell, W. (1967). British Fournal of Dermatology, 79, 487.

Scoggins, R. B. (1962). Fournal of Investigative Dermatology, 39, 473. Scoggins, R. B., and Kliman, B. (1965). New England fourmal of Medicine, 273, 831

Truelove, S. C., and Morris-Owen, R. M. (1958). British Medical fournal, 1, 603 .

Wood, J. B., Frankland, A. W., James, V. H. T., and Landon, J. (1965). Lancet, 1, 243.

\title{
Toxoplasma Infection in an Urban Community
}

\author{
J. H. PRICE,* M.B., CH.B., M.R.C.G.P.
}

\begin{abstract}
Summary : A survey was undertaken in an urban com$\checkmark$ munity to examine the intrafamilial epidemiology of toxoplasma infection and its relation to a set of environmental variables. Statistically significant relations were found with (a) ownership of a dog or cat ; (b) the handling of pet food, particularly cat food; and (c) a " risk" score compounded from the handling of pet food and lack of cleanliness in the kitchen.
\end{abstract}

\section{Introduction}

It has been known for several years that toxoplasmosis occurs in adults of 50 years and over, and that the infection, though usually very mild, can be fatal (Kass et al., 1952). Particularly is this true when it is associated with other diseases (Hemsath and Pinkerton, 1956). Glandular toxoplasmosis in people aged 50 and over can give rise to difficult diagnostic problems, as the glands may resemble tuberculous or neoplastic lymph nodes (Beverley and Beattie, 1958 ; British Medical fournal, 1968).

An excellent survey of the possible modes of human infection by Toxoplasma gondii is given by Hutchinson (1967), but most epidemiological and clinical surveys do not specifically deal with older age groups.

The present survey, carried out in an urban general practice and based on the dye test of Sabin and Feldman (1948), is a study of the epidemiology of the disease in this age group.

\section{Materials and Methods}

Sixty European men aged between 51 and 59 years, who visited a general practitioner in his consulting-room during the 12 months April 1967 to March 1968, agreed to have blood

\footnotetext{
- General Practitioner, Birmingham.
}

D taken for the toxoplasma dye test. Records were then searched to find if the patients were married and had wives on the practice list, and, if so, the man and his wife were admitted to the study.

A visit was made to the homes of these husbands and wives and a sample of blood was obtained from the wife also. A health inspector, who was not acquainted with the serological results, visited and completed a questionary. At the same time he assessed the cleanliness of the kitchen and bedroom on a simple three-point scale.

The questions on the form recorded recent and remote contacts with domestic pets (cats, dogs, rabbits, pet mice, and budgerigars), contact with wild mice and rats, the "worming" of pets, flea infestation, details of holidays and service abroad, handling of raw meat for human consumption in the home, handling of pet food, salad eating, and gardening. All these have been suggested as possible factors in the transmission of toxoplasma infection to man. A question concerning the ownership of goldfish was added as a "negative check."

Six of the original 60 men were not married, five had wives who were not on the practice list, two had wives who were in hospital, two wives declined to give samples of blood, one husband and wife moved from the area, and one of the husbands died during the period of investigation. This left 43 households where it was possible to complete the inquiry.

The dye tests based on the technique of Sabin and Feldman (1948) were performed at the Public Health Laboratory at Swansea, the results being added to the form. The findings were transferred to punch cards for analysis and a computer programme was used for statistical evaluation of the results.

Tables were made to compare dye test titres with each of the variables, and analysis of variance was done by the Snedecor test to obtain $F$ values. 